Vegetalika. 2018. 7(4): 12-25

\title{
Karakter Morfologi Akar dan Hasil Padi Ratun (Oryza sativa L.) pada Perbedaan Waktu dan Tinggi Pemotongan Tunggul Sisa Panen
}

\section{Root Morphology and Yield of Rice Ratoon (Oryza sativa L.) on Varied Time and Cutting Height of Stubble}

\author{
Ananta Bayu Pratama, Didik Indradewa*), Erlina Ambarwati \\ Departemen Budidaya Pertanian, Fakultas Pertanian, Universitas Gadjah Mada \\ *) Penulis untuk koresponden Email: didikindradewa54@yahoo.com
}

\begin{abstract}
This research was aimed to determine the optimal cutting time and optimal height of rice stubble to support root growth to achieve the maximum productivity of rice ratoon. This research was arranged in Split-Plot Randomized Complete Block Design (RCBD) with two factors and three blocks as replications. The main plot was varied cutting time of stubble that consist of three levels, i.e. (0 day after harvesting), 7 day after harvesting, and 14 days after harvesting. The sub-plot was stubble cutting height that consist of four level which were $4 \mathrm{~cm}, 14 \mathrm{~cm}, 24 \mathrm{~cm}$, and $34 \mathrm{~cm}$. Observed variables were root morphology and yield. Data were analyzed with Analysis of Variance (ANOVA) at 95\% significance level, continued with orthogonal polinomial test. Correlation between variable was determined by analysis of correlation. The result showed that varied cutting time of stubble affected the root diameter, the biggest root diameter $(0,89 \mathrm{~mm})$ was achieved if stubble was cutted at 10 day after harvested and stubble cutting height at $4 \mathrm{~cm}$ above ground surface. The longest vegetative phase (44 days) and highest productivity (3,393,54 ton/ha) was achieved if stubble was cutted at $4 \mathrm{~cm}$ above ground surface, however varied cutting time was not affect to both variables.
\end{abstract}

Keywords: cutting, height, ratoon, root, time.

\section{INTISARI}

Penelitian ini bertujuan untuk menentukan waktu dan tinggi pemotongan tunggul sisa panen yang optimal untuk mendukung pertumbuhan akar sehingga diperoleh daya hasil padi ratun maksimal. Percobaan lapangan disusun dalam Rancangan Acak Lengkap split plot 2 faktor dan 3 blok sebagai ulangan. Percobaan lapangan disusun dalam Rancangan Acak Kelompok Lengkap split plot 2 faktor dan 3 blok sebagai ulangan. Petak utama berupa waktu pemotongan tunggul, terdiri dari 3 taraf yaitu: saat panen $(0 \mathrm{HSP}), 7$ hari setelah panen (7 HSP) dan 14 hari setelah panen (14 HSP). Anak petak berupa tinggi pemotongan tunggul, terdiri dari 4 taraf yaitu: $4 \mathrm{~cm}, 14 \mathrm{~cm}, 24 \mathrm{~cm}$ dan $34 \mathrm{~cm}$. Variabel yang diamati berupa variabel morfologi akar dan hasil padi ratun. Data yang diperoleh dianalisis varians (ANOVA) dengan taraf kepercayaan 95\%, dilanjutkan dengan uji polinomial orthogonal. Hubungan antar variabel pengamatan ditentukan dengan analisis korelasi. Hasil penelitian memberi informasi bahwa waktu pemotongan tunggul sisa panen hanya berpengaruh nyata terhadap diameter akar dengan waktu pemotongan terbaik 10 HSP yang menghasilkan diameter terbesar 0,89 mm, ketika dilakukan pemotongan 
tunggul setinggi $4 \mathrm{~cm}$ di atas permukaan tanah, namun tidak berpengaruh nyata terhadap sifat perakaran lainnya. Fase vegetatif yang paling lama (44 hari) dan produktivitas gabah yang paling tinggi $(3,39-3,54$ ton/ha) diperoleh bila tunggul dipotong setinggi $4 \mathrm{~cm}$ di atas permukaan tanah, namun perbedaan waktu pemotongan tunggul tidak berpengaruh nyata terhadap kedua variabel tersebut.

Kata kunci: akar, pemotongan, ratun, tinggi, waktu.

\section{PENDAHULUAN}

Padi ratun (ratoon) adalah tanaman padi yang berasal dari tunas yang tumbuh dari tunggul yang telah dipanen dan menghasilkan anakan baru hingga dapat dipanen. Budidaya padi secara ratun belum banyak diterapkan oleh petani karena umumnya padi ratun memiliki daya hasil yang lebih rendah dibanding tanaman pertama. Daya hasil yang tinggi sebenarnya dapat diperoleh jika manajemen budidaya ratun dilakukan dengan baik (Nainggolan et al., 2013).

Salah satu faktor penting dalam budidaya padi ratun yang harus diperhatikan adalah pemotongan tunggul sisa panen. Pemotongan tunggul berpengaruh terhadap pertumbuhan dan perkembangan tunas ratun serta hasil padi ratun. Menurut BertrandMorvan et al. (1999), cadangan asimilat berupa karbohidrat pada tunggul tanaman rumput-rumputan akan berpengaruh terhadap karakter morfologi ratunnya. Menurut Abdulrachman et al. (2015), produktivitas gabah yang tinggi akan diperoleh bila dilakukan pemotongan ulang tunggul pada 7 - 10 hari setelah panen (HSP). Vergara et al. (1985), menyatakan bahwa tunas ratun akan mulai tumbuh pada $4-6$ hari setelah panen. Ichii (1988) menyebutkan bahwa untuk menumbuhkan tunas ratun diperlukan energi yang sangat besar sehingga kebutuhan asimilatnya juga semakin besar, sehingga apabila dilakukan pemotongan ulang pada $7-10 \mathrm{HSP}$, tunggul akan mengalami banyak kehilangan cadangan asimilat.

Tinggi pemotongan tunggul juga diketahui berpengaruh terhadap penggunaan dan ketersediaan cadangan asimilat pada tunggul sisa panen. Cadangan asimilat pada tunggul padi disimpan di pangkal batang (Ichii, 1988). Pemotongan tunggul yang tinggi menyebabkan beban penggunaan cadangan asimilat menjadi lebih besar, karena semakin tinggi tunggul yang tersisa maka semakin banyak pula sel dari organ tersisa yang membutuhkan energi yang dihasilkan dari aktivitas katabolisme (Chiangmai dan Yodmingkhwan, 2011). Oleh karena itu, agar laju penurunan cadangan asimilatnya berjalan lebih lambat, beban penggunaan asimilat harus dikurangi dengan cara pemotongan tunggul yang pendek, namun pemotongan tunggul yang pendek berisiko 
Ananta Bayu Pratama et al., / Vegetalika. 2018. 7(4): 12-25

mengurangi jumlah buku yang tersisa sehingga potensi tumbuhnya tunas dari setiap tunggul akan berkurang.

Pemotongan tunggul sisa panen diduga juga berpengaruh terhadap pertumbuhan akar padi ratun kaitannya dengan faktor pendukung pertumbuhan akar. Pembentukan akar baru membutuhkan energi yang besar yang berasal dari cadangan asimilat (Ichii, 1954), kelembaban tinggi (Blum dan Ritchie, 1984) dan peran hormon (Kitomi et al., 2011). Akar menjadi salah satu organ yang memiliki peran yang sangat penting bagi pertumbuhan dan perkembangan padi ratun. Produksi gabah sebagian besar dipengaruhi oleh kecukupan unsur hara, organ yang memegang peranan penting dalam hal ini adalah akar (Slaton et al., 1990)

Akar padi ratun, seperti halnya akar padi non-ratun tumbuh dari bagian pangkal batang. Berbeda dengan padi non-ratun, padi ratun memiliki pangkal batang yang lebih banyak, karena tunas ratun yang tumbuh juga akan membentuk pangkal batang (Dunand dan Saichuk, 1999). Jumlah pangkal batang yang lebih banyak ini menjadikan padi ratun berpeluang untuk memiliki organ penyerapan air dan hara yang lebih banyak, meskipun demikian fakta di lapangan menunjukkan bahwa padi ratun cenderung memiliki daya hasil yang lebih rendah dibanding tanaman pertamanya.

Pada budidaya padi ratun pertumbuhan dan perkembangan akar baru sangatlah penting untuk menggantikan peran dari akar lama. Pertumbuhan akar baru pada padi ratun akan mempengaruhi kemampuan menghasilkan fotosintat yang akhirnya berpengaruh pada pembentukan organ baru dan komponen hasil. Diperlukan kajian ilmiah mengenai pengaruh manajemen budidaya, dalam hal ini adalah waktu dan tinggi pemotongan ulang tunggul sisa panen terhadap pertumbuhan dan hasil padi ratun, khususnya dinamika pertumbuhan akar yang berkaitan dengan pertumbuhan dan hasil padi ratun.

\section{BAHAN DAN METODE PENELITIAN}

Alat-alat yang digunakan dalam penelitian ini meliputi cangkul, sabit, treaser, hand sprayer, termohigrometer (HTC-2), lux meter (Lutron LX-107), soil sampling core (bor tanah diameter 27,3 mm), screen net, timbangan analitik (ACIS AD-300i 300 $\mathrm{g}$ 0,01g dan Shimadzu AW220 220g x 0,1 mg), leaf area meter (AT Area Meter MK2), jangka sorong, pinset, oven (WTC Binder 7200), kantong plastik, ember, rafia, ajir bambu, label, alat tulis dan kamera handphone Asus Z2007. Bahan-bahan yang digunakan dalam penelitian ini meliputi pertanaman padi sawah kultivar Ciherang yang hampir masuk umur panen, lahan 
Ananta Bayu Pratama et al., / Vegetalika. 2018. 7(4): 12-25

sawah seluas $900 \mathrm{~m}^{2}$, air irigasi, pupuk Urea, SP36, $\mathrm{KCl}$, insektisida Imidor $50 \mathrm{SL}$ dan herbisida Ally Plus 70 WP.

Variabel yang diamati berupa variabel morfologi akar dan hasil. Variabel pertumbuhan tunas ratun diamati pada awal fase generatif yang meliputi letak buku tempat tumbuh tunas dan jarak antara tunas dengan permukaan tanah. Pengambilan sampel untuk pengamatan variabel morfologi akar dilakukan dengan metode washed soil core (Gregory, 2006). Data-data yang diambil dalam pengamatan variabel morfologi akar meliputi kerapatan bobot kering akar dan diameter akar. Variabel hasil berupa produktivitas padi ratun. Data yang diperoleh dianalisis varians (ANOVA) taraf kepercayaan 95\%, dilanjutkan dengan uji polinomial orthogonal. Hubungan antar variabel pengamatan ditentukan dengan analisis korelasi. Data diolah dengan menggunakan perangkat lunak SAS versi 9.4. serta $R$ versi 3.0.2.

\section{HASIL DAN PEMBAHASAN}

Kerapatan bobot kering akar merupakan parameter yang sangat penting untuk menggambarkan kemampuan pembentukan biomassa dalam bentuk akar setiap satuan volume tanah tertentu. Peningkatan $10 \mathrm{~cm}$ tinggi pemotongan tunggul menyebabkan penurunan kerapatan bobot kering akar padi ratun sebesar $0,51 \mathrm{mg} / \mathrm{cm}^{3}$ di jeluk $0-5 \mathrm{~cm}$ (Gambar 1.). Pada penelitian ini, kerapatan bobot kering akar terbesar diperoleh bila tunggul dipotong setinggi $4 \mathrm{~cm}$ di atas permukaan tanah. Nilai kerapatan bobot kering akar menggambarkan besaran dimensi perakaran sebagai hasil dari pertumbuhan akar (Morita dan Abe, 1994). Hal ini menandakan bahwa perlakuan pemotongan pada ketinggian tersebut menyebabkan pertumbuhan akar baru padi ratun lebih baik sehingga dimensi akarnya lebih besar jika dibandingkan dengan perlakuan lainnya. Dimensi akar ini erat kaitannya dengan kemampuan akar dalam mengeksplorasi dan menyerap unsur hara dan air. 


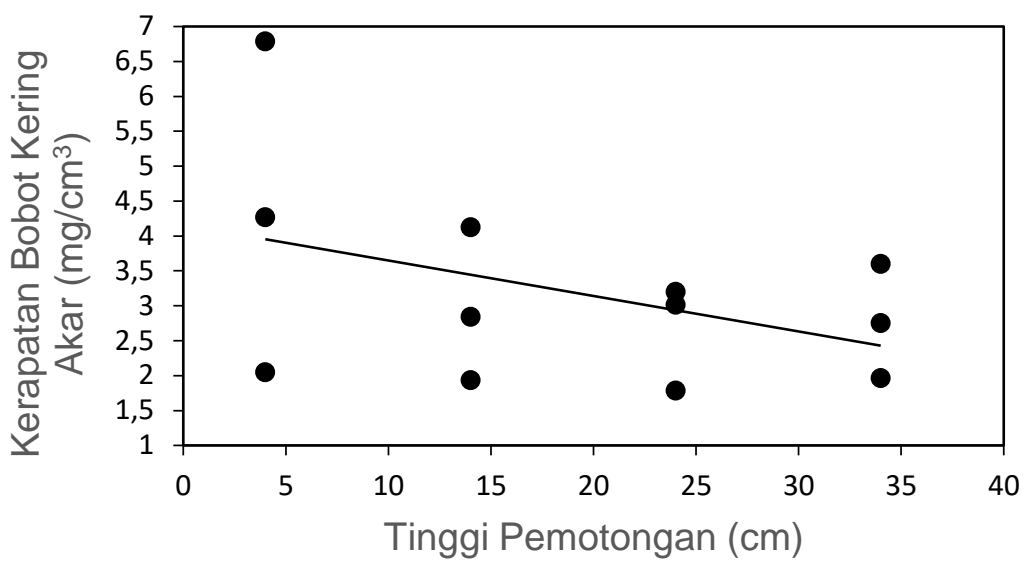

Gambar 1. Hubungan antara tinggi pemotongan tunggul dengan kerapatan bobot kering akar padi ratun di jeluk $0-5 \mathrm{~cm}\left(\mathrm{Y}=-0,0506 \mathrm{X}+4,1565 ; \mathrm{R}^{2}=0,1775 ; P<0,05\right)$ pada saat panen

Ukuran diameter akar padi ratun menggambarkan kerapatan percabangan akar, dimana besar kecilnya kerapatan percabangan ini menggambarkan dimensi akar padi (Wu et al., 2016). Umumnya akar primer memiliki ukuran diameter yang lebih besar diikuti akar sekunder, tersier dan kuartener. Selain menggambarkan jenis akar, diameter akar padi juga menggambarkan ukuran diameter berkas pengangkutnya (Yamazaki dan Nemoto, 1986 cit. Morita dan Nemoto, 1995). Peningkatan tinggi pemotongan tunggul menyebabkan penurunan ukuran diameter akar.

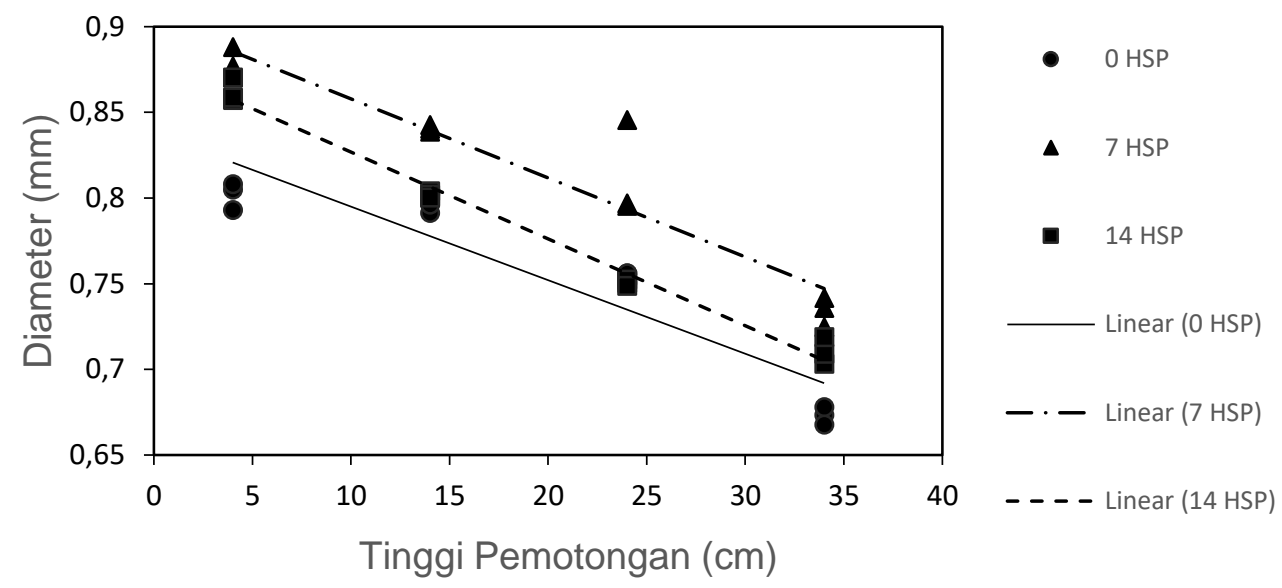

Gambar 2. Hubungan antara tinggi pemotongan dengan diameter akar padi ratun di jeluk $0-5 \mathrm{~cm}$ pada fase vegetatif ketika tunggul dipotong pada $0 \mathrm{HSP}\left(\mathrm{Y}=-0.0043 \mathrm{X}+0.8379 ; \mathrm{R}^{2}=0.8585\right.$;

$P<0,05), 7$ HSP $\left(Y=-0,0046 X+0,904 ; R^{2}=0,8952 ; P<0,05\right)$ dan 14 HSP $(Y=-0,0051 X+0,8775$; $\left.R^{2}=0,9864 ; P<0,05\right)$

Peningkatan tinggi pemotongan tunggul menyebabkan penurunan ukuran diameter akar padi ratun di jeluk $0-5 \mathrm{~cm}$ pada fase vegetatif, baik ketika tunggul dipotong pada 0 HSP, 7 HSP, maupun pada 14 HSP (Gambar 2.). Peningkatan tinggi pemotongan tunggul sebesar $10 \mathrm{~cm}$ menyebabkan penurunan ukuran diameter akar padi ratun di jeluk ini sebesar $0,04 \mathrm{~mm}$ ketika tunggul dipotong pada $0 \mathrm{HSP}$. Ketika tunggul 
Ananta Bayu Pratama et al., / Vegetalika. 2018. 7(4): 12-25

dipotong pada 7 HSP dan 14 HSP, peningkatan tinggi pemotongan tunggul sebesar 10 $\mathrm{cm}$ menyebabkan penurunan ukuran diameter akar padi ratun sebesar 0,05 mm.

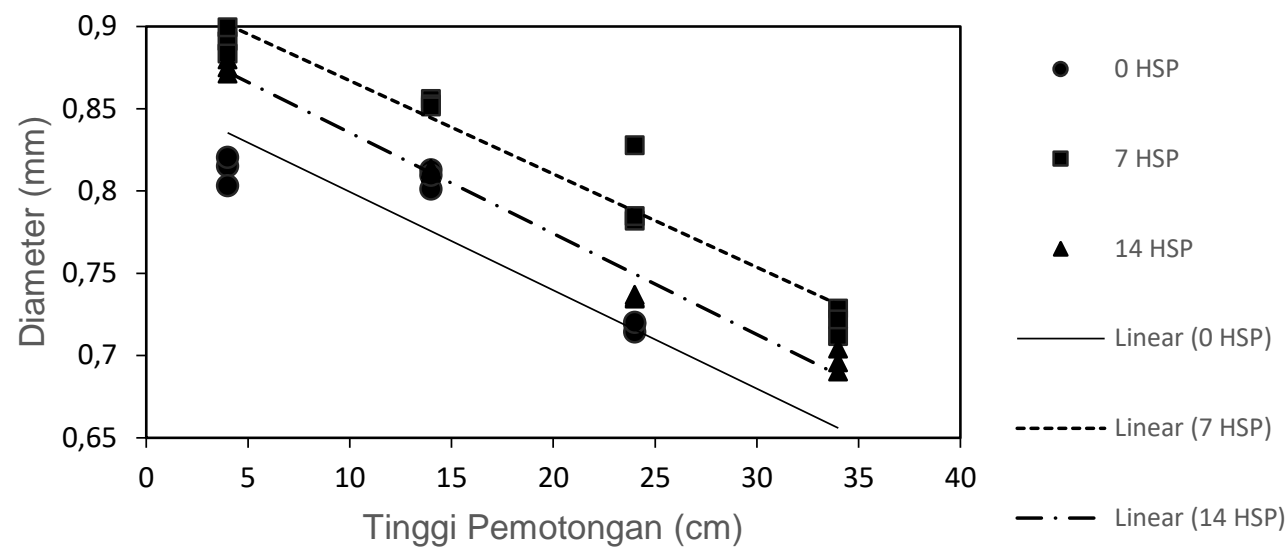

Gambar 3. Hubungan antara tinggi pemotongan dengan diameter akar padi ratun di jeluk $0-5 \mathrm{~cm}$ pada awal fase generatif ketika tunggul dipotong pada $0 \mathrm{HSP}\left(\mathrm{Y}=-0.006 \mathrm{X}+0.8593 ; \mathrm{R}^{2}=0.9085\right.$;

$\mathrm{P}<0,05), 7 \mathrm{HSP}\left(\mathrm{Y}=-0.0057 \mathrm{X}+0.9238 ; \mathrm{R}^{2}=0.9458 ; \mathrm{P}<0,05\right)$ dan $14 \mathrm{HSP}(\mathrm{Y}=-0.0061 \mathrm{X}+$ $\left.0.8968 ; R^{2}=0.9827 ; P<0,05\right)$

Pada awal fase generatif, peningkatan tinggi pemotongan tunggul juga menyebabkan terjadinya penurunan ukuran diameter akar. Peningkatan tinggi pemotongan tunggul sebesar $10 \mathrm{~cm}$ menyebabkan terjadinya penurunan diameter akar padi ratun sebesar $0,06 \mathrm{~mm}$, baik ketika tunggul dipotong pada $0 \mathrm{HSP}, 7 \mathrm{HSP}$, maupun 14 HSP (Gambar 3.).

Pola kecenderungan penurunan ukuran diameter akar padi ratun seiring dengan peningkatan tinggi pemotongan tunggul juga terjadi di saat panen padi ratun. Peningkatan tinggi pemotongan tunggul sebesar $10 \mathrm{~cm}$ menyebabkan penurunan ukuran diameter akar sebesar 0,05 mm ketika tunggul dipotong pada 0 HSP dan 14 HSP. Pemotongan tunggul pada $7 \mathrm{HSP}$, penurunan ukuran diameter akar sebesar 0,04 mm terjadi bila pemotongan tunggul dinaikkan sebesar $10 \mathrm{~cm}$ (Gambar 4.). 
Ananta Bayu Pratama et al., / Vegetalika. 2018. 7(4): 12-25
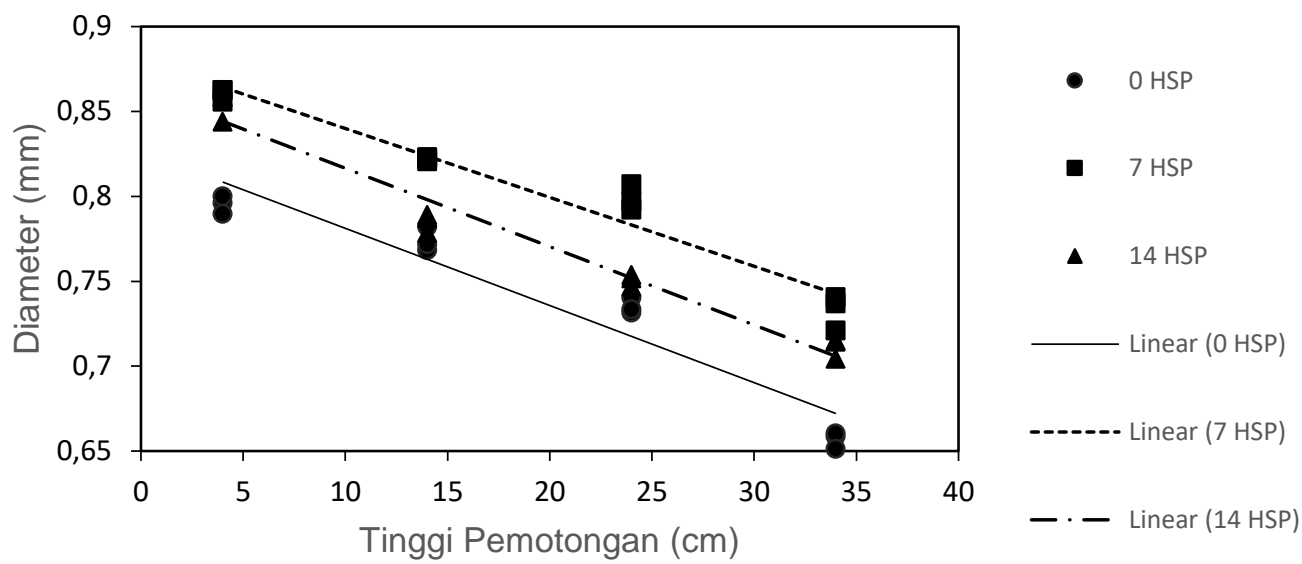

Gambar 4. Hubungan antara tinggi pemotongan dengan diameter akar padi ratun di jeluk $0-5 \mathrm{~cm}$ pada saat panen ketika tunggul dipotong pada $0 \mathrm{HSP}\left(\mathrm{Y}=-0.0045 \mathrm{X}+0.8266 ; \mathrm{R}^{2}=0.9178\right.$; $\mathrm{P}<0,05), 7 \mathrm{HSP}\left(\mathrm{Y}=-0.0041 \mathrm{X}+0.8805 ; \mathrm{R}^{2}=0.9447 ; \mathrm{P}<0,05\right)$ dan $14 \mathrm{HSP}(\mathrm{Y}=-0.0046 \mathrm{X}+$ $\left.0.8627 ; R^{2}=0.9644 ; P<0,05\right)$.

Pemotongan tunggul setinggi $4 \mathrm{~cm}$ di atas permukaan tanah menghasilkan akar padi dengan diameter yang paling besar jika dibandingkan dengan perlakuan tinggi pemotongan tunggul lainnya (Gambar 2., Gambar 3. dan Gambar 4.). Diameter yang lebih besar ini disebabkan karena berbeda dengan tinggi pemotongan tunggul lainnya, pada pemotongan tunggul $4 \mathrm{~cm}$ di atas permukaan tanah, letak tumbuh tunas ratun berada pada buku yang berada di dekat permukaan tanah atau bahkan di dalam permukaan tanah. Tunas yang tumbuh di permukaan tanah/di dalam tanah memungkinkan pertumbuhan akar baru dari pangkal batang tunas ratun karena didukung lingkungan tumbuh yang ideal, khususnya kelembaban. Akar baru yang tumbuh dari pangkal batang ini merupakan akar primer dengan ukuran yang lebih besar jika dibandingkan dengan akar lateral (Gu et al., 2017). Pertumbuhan akar primer ini menyebabkan peningkatan rasio akar primer dengan akar lateral pada padi ratun yang berasal dari tunggul yang dipotong setinggi $4 \mathrm{~cm}$ di atas permukaan tanah.

Thaler dan Pages (1996) cit Wu et al. (2016), besar kecilnya diameter akar yang terbentuk dipengaruhi oleh ketersediaan cadangan asimilat. Perbedaan waktu dan tinggi pemotongan tunggul sisa panen diduga kuat berpengaruh terhadap ketersediaan cadangan asimilat yang tersisa, sehingga berpengaruh juga terhadap ukuran diameter akar baru padi ratun yang terbentuk. Berdasarkan Gambar 5. pemotongan tunggul setinggi $4 \mathrm{~cm}$ di atas permukaan tanah akan menghasilkan diameter akar terbesar di jeluk 0 - $5 \mathrm{~cm}$ pada fase vegetatif apabila tunggul dipotong pada 9,78 HSP (10 HSP) senilai $0,89 \mathrm{~mm}$. Tunggul yang dipotong setinggi $14 \mathrm{~cm}$ di atas permukaan tanah menghasilkan ukuran diameter akar padi ratun terbesar senilai $0,84 \mathrm{~mm}$ bila dipotong pada 7,63 HSP (8 HSP). Pada pemotongan tunggul setinggi $24 \mathrm{~cm}$ di atas permukaan tanah, tanggapan 
Ananta Bayu Pratama et al., / Vegetalika. 2018. 7(4): 12-25

diameter akar terbesar senilai $0,81 \mathrm{~mm}$ diperoleh bila tunggul dipotong pada 7,08 HSP (8 HSP). Pada pemotongan tunggul yang lebih tinggi lagi, yaitu $34 \mathrm{~cm}$ di atas permukaan tanah, diameter terbesar senilai $0,73 \mathrm{~mm}$ diperoleh bila tunggul dipotong pada $8,22 \mathrm{HSP}$ (8 HSP).
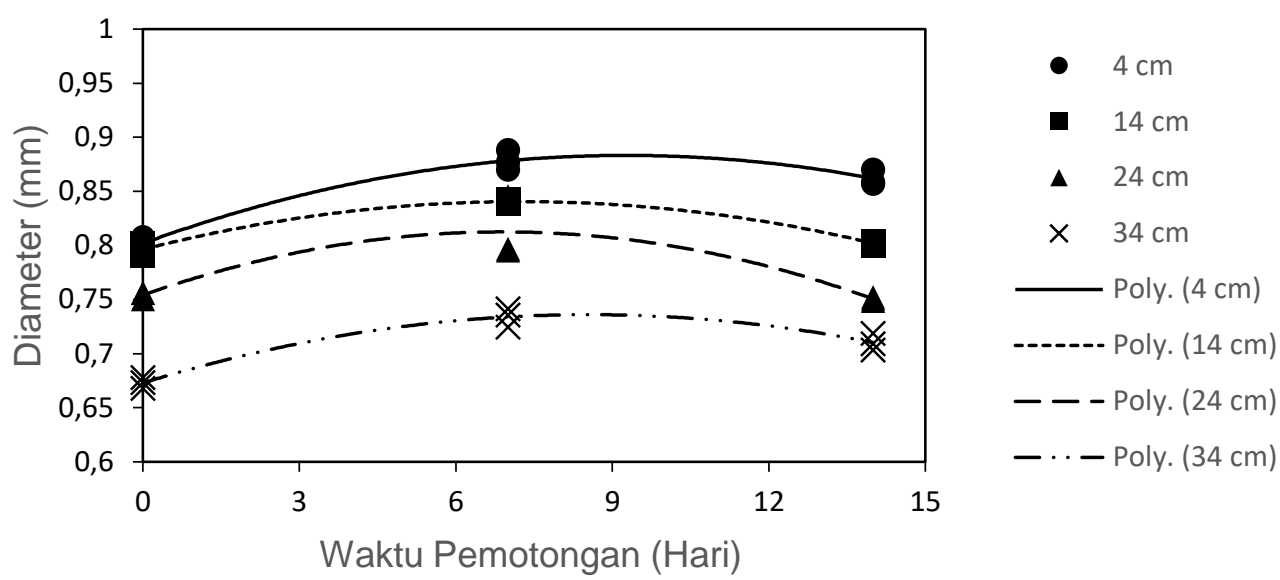

Gambar 5. Hubungan antara waktu pemotongan tunggul dengan diameter akar padi ratun jeluk $0-$ $5 \mathrm{~cm}$ pada fase vegetatif ketika tunggul dipotong setinggi $4 \mathrm{~cm}\left(\mathrm{Y}=-0.0009 \mathrm{X}^{2}+0.0176 \mathrm{X}+0.8019\right.$; $\left.R^{2}=0.9617 ; P<0,05\right), 14 \mathrm{~cm}\left(Y=-0.0008 X^{2}+0.0122 X+0.7964 ; R^{2}=0.9793 ; P<0,05\right), 24 \mathrm{~cm}(Y=$

$\left.-0.0008 X^{2}+0.0122 X+0.7964 ; R^{2}=0.9793 ; P<0,05\right)$ dan $34 \mathrm{~cm}$ di atas permukaan tanah $(Y=-$ $\left.0.0008 X^{2}+0.0122 X+0.7964 ; R^{2}=0.9793 ; P<0,05\right)$.

Pada awal fase generatif, pemotongan tunggul pada $4 \mathrm{~cm}$ di atas permukaan tanah akan menghasilkan diameter akar terbesar di jeluk $0-5 \mathrm{~cm}$ senilai $0,89 \mathrm{~mm}$ bila tunggul dipotong pada $9 \mathrm{HSP}$. Tanggapan yang berbeda terjadi bila pemotongan tunggul dinaikkan menjadi $14 \mathrm{~cm}$ di atas permukaan tanah, diameter akar padi ratun terbesar di jeluk tersebut sebesar $0,85 \mathrm{~mm}$ akan diperoleh bila pemotongan dilakukan pada $7 \mathrm{HSP}$. Pemotongan tunggul setinggi $24 \mathrm{~cm}$ di atas permukaan tanah akan menghasilkan diameter akar terbesar senilai $0,80 \mathrm{~mm}$ bila pemotongan dilakukan pada $7,23 \mathrm{HSP}$ (7HSP). Pada pemotongan tunggul yang lebih tinggi lagi, yaitu $34 \mathrm{~cm}$ di atas permukaan tanah diameter akar terbesar pada awal fase generatif di jeluk ini sebesar 0,73 mm akan diperoleh jika tunggul dipotong pada 9,23 HSP (9 HSP) (Gambar 6). 
Ananta Bayu Pratama et al., / Vegetalika. 2018. 7(4): 12-25

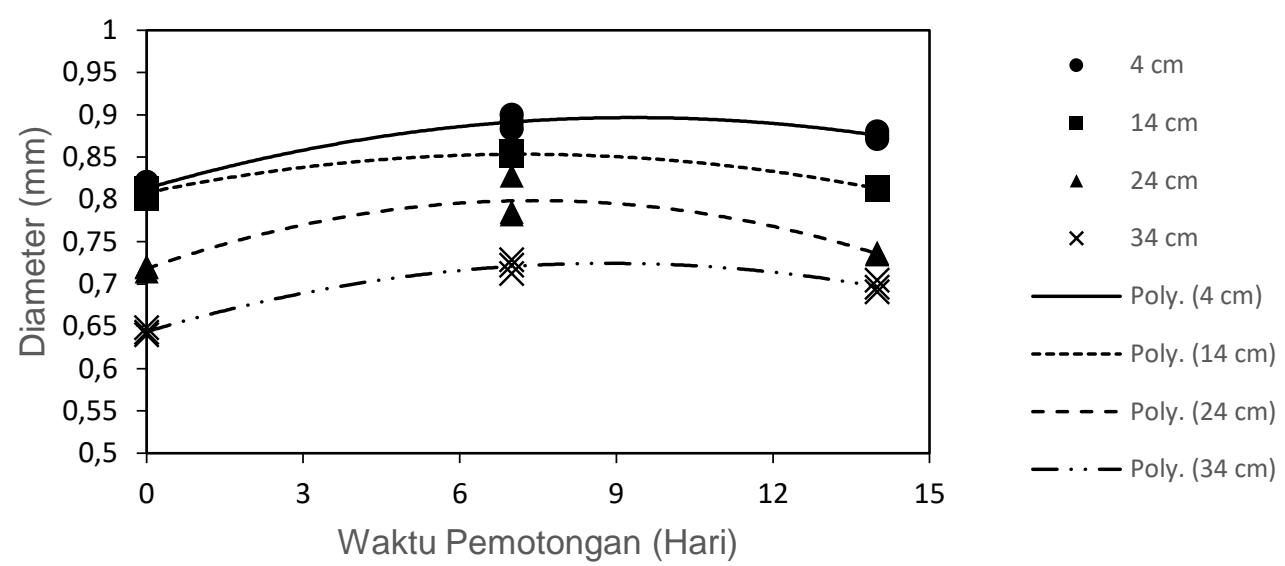

Gambar 6. Hubungan antara waktu pemotongan tunggul dengan diameter akar padi ratun jeluk $0-$

$5 \mathrm{~cm}$ pada awal fase generatif ketika tunggul dipotong setinggi $4 \mathrm{~cm}\left(\mathrm{Y}=-0.001 \mathrm{X}^{2}+0.018 \mathrm{X}+\right.$ 0.813; $\left.R^{2}=0.9698 ; P<0,05\right), 14 \mathrm{~cm}\left(Y=-0.0009 X^{2}+0.0126 X+0.808 ; R^{2}=0.9771 ; P<0,05\right), 24$ $\mathrm{cm}\left(\mathrm{Y}=-0.0015 \mathrm{X}^{2}+0.0217 \mathrm{X}+0.7181 ; \mathrm{R}^{2}=0.888 ; \mathrm{P}<0,05\right)$ dan $34 \mathrm{~cm}$ di atas permukaan tanah $\left(Y=-0.001 X^{2}+0.0183 X+0.6436 ; R^{2}=0.9718 ; P<0,05\right)$
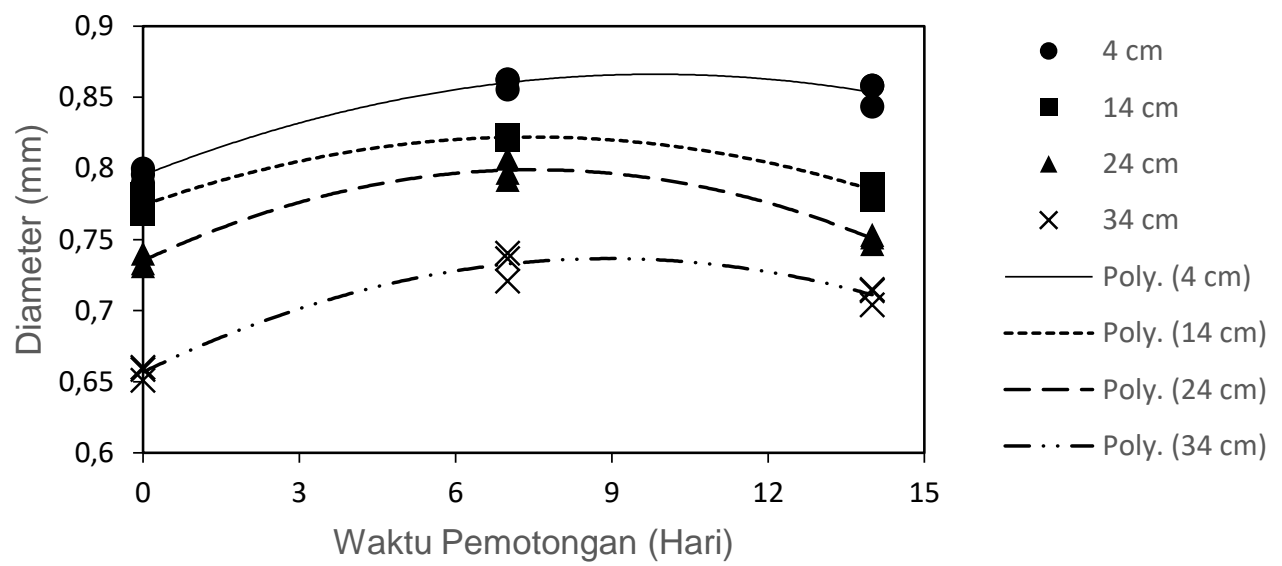

Gambar 7. Hubungan antara waktu pemotongan tunggul dengan diameter akar padi ratun jeluk $0-$ $5 \mathrm{~cm}$ pada saat panen ketika tunggul dipotong setinggi $4 \mathrm{~cm}\left(\mathrm{Y}=-0.0007 \mathrm{X}^{2}+0.0144 \mathrm{X}+0.7952\right.$; $\left.R^{2}=0.9711 ; P<0,05\right), 14 \mathrm{~cm}\left(Y=-0.0008 X^{2}+0.0124 X+0.7741 ; R^{2}=0.7659 ; P<0,05\right), 24 \mathrm{~cm}(Y=$ $\left.-0.0011 \mathrm{X}^{2}+0.0171 \mathrm{X}+0.7351 ; \mathrm{R}^{2}=0.9731 ; \mathrm{P}<0,05\right)$ dan $34 \mathrm{~cm}$ di atas permukaan tanah $(\mathrm{Y}=-$ $\left.0.001 X^{2}+0.0178 X+0.6567 ; R^{2}=0.965 ; P<0,05\right)$

Pada umur panen, akar padi ratun dari pemotongan tunggul setinggi $4 \mathrm{~cm}$ di atas permukaan tanah memberi tanggapan diameter terbesar pada saat panen di jeluk $0-5$ cm senilai 0,87 mm bila tunggul dipotong pada 10,29 HSP (10 HSP). Pada pemotongan tunggul setinggi $14 \mathrm{~cm}$ di atas permukaan tanah, diameter akar terbesar sebesar 0,80 mm diperoleh jika tunggul dipotong saat 7,77 HSP (8 HSP). Pemotongan tunggul setinggi 24 $\mathrm{cm}$ di atas permukaan tanah akan menghasilkan diameter akar terbesar senilai $0,81 \mathrm{~mm}$ apabila tunggul dipotong pada 7,08 HSP (7 HSP). Pada pemotongan tunggul setinggi 34 $\mathrm{cm}$ di atas permukaan tanah, akar padi ratun memberi tanggapan diameter terbesar di jeluk $0-5 \mathrm{~cm}$ senilai $0,74 \mathrm{~mm}$ bila tunggul dipotong pada 8,9 HSP (9 HSP) (Gambar 7.). 


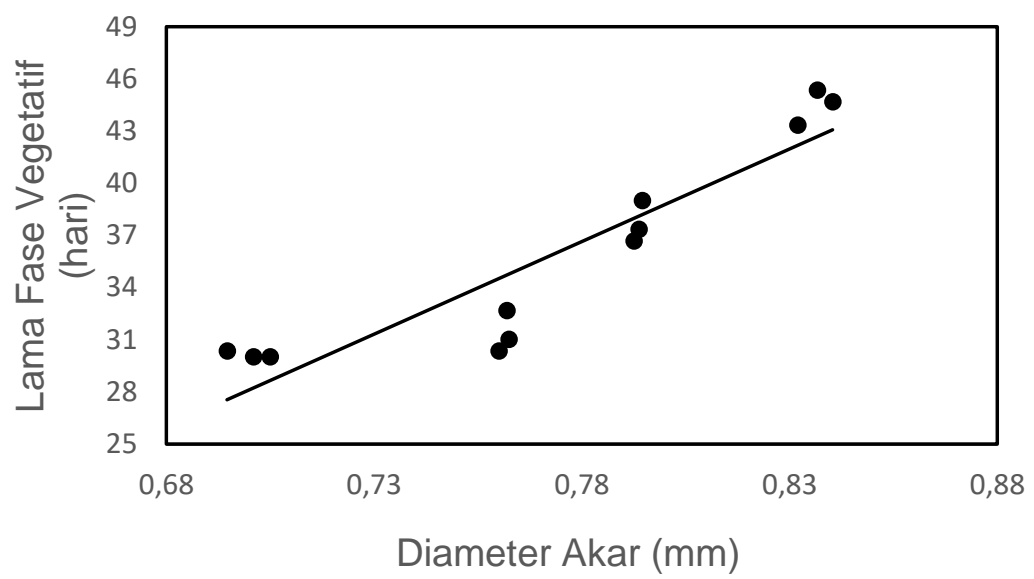

Gambar 8. Hubungan antara diameter akar padi ratun dengan lama fase vegetatif padi ratun $(Y=$ $\left.106,49 X-46,415 ; R^{2}=0,8433 ; P<0,05\right)$

Ukuran diameter akar padi ratun berpengaruh terhadap lama fase vegetatif padi ratun. Semakin besar ukuran diameter akarnya, semakin lama fase vegetatifnya. Bertambahnya ukuran diameter akar sebesar 0,1 $\mathrm{mm}$ menyebabkan padi ratun memiliki fase vegetatif 10,7 hari lebih lama (Gambar 8.). Padi ratun yang memiliki ukuran diameter akar yang lebih besar memiliki dimensi perakaran yang lebih besar. Dimensi perakaran yang besar memungkinkan padi ratun memiliki kemampuan penyerapan air dan unsur hara yang lebih baik. Kemampuan penyerapan unsur hara didukung oleh ukuran diameter berkas pengangkut, sehingga aktivitas pembentukan fotosintat berjalan dengan baik. Kemampuan penyerapan unsur hara yang baik, terutama unsur $\mathrm{N}$ berpengaruh terhadap lama fase vegetatif tanaman. Penyerapan unsur $\mathrm{N}$ berpengaruh terhadap nisbah $\mathrm{C} / \mathrm{N}$ di dalam tanaman. Nisbah $\mathrm{C} / \mathrm{N}$ yang tinggi akan menginduksi pembungaan tanaman (Corbesier et al., 2002). Padi ratun yang memiliki kemampuan penyerapan unsur $\mathrm{N}$ yang besar membutuhkan waktu yang lebih lama untuk mencapai nilai nisbah $\mathrm{C} / \mathrm{N}$ yang tinggi, sehingga lama fase vegetatifnya lebih panjang.

Fase vegetatif yang lebih lama memungkinkan padi ratun untuk membentuk organ vegetatif yang lebih banyak. Gambar 9. menunjukkan bahwa bertambahnya lama fase vegetatif selama 10 hari menyebabkan peningkatan produktivitas padi ratun sebesar 0,83 ton/ha. Hal ini disebabkan karena lama fase vegetatif dan jumlah organ vegetatif yang terbentuk berkorelasi positif terhadap kemampuan pembentukan dan penimbunan biomassa, salah satunya terekspresikan dalam bentuk gabah isi (Makarim dan Suhartatik, 2006). 
Ananta Bayu Pratama et al., / Vegetalika. 2018. 7(4): 12-25

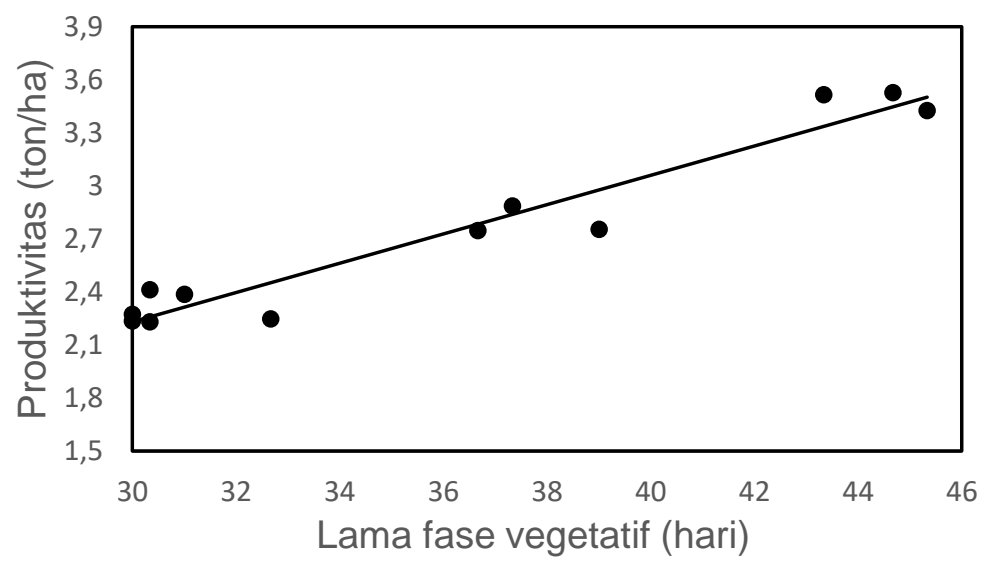

Gambar 9. Hubungan antara diameter akar padi ratun dengan lama fase vegetatif padi ratun $(\mathrm{Y}=$ $\left.0,0829 X-0,2561 ; R^{2}=0,9412 ; P<0,05\right)$

Kenaikan $10 \mathrm{~cm}$ tinggi pemotongan menyebabkan penurunan produktivitas padi ratun sebesar 0,38 ton/ha ( $0 \mathrm{HSP}$ ) dan 0,5 ton/ha (14 HSP), sedangkan pada pemotongan saat $7 \mathrm{HSP}$, produktivitas terendah sebesar 1,94 ton/ha diperoleh bila tunggul dipotong pada $24,04 \mathrm{~cm}$ di atas permukaan tanah. Pemotongan tunggul setinggi 4 $\mathrm{cm}$ di atas permukaan tanah menghasilkan produktivitas padi ratun tertinggi yaitu sebesar 3,39 - 3,54 ton/ha (Gambar 10).

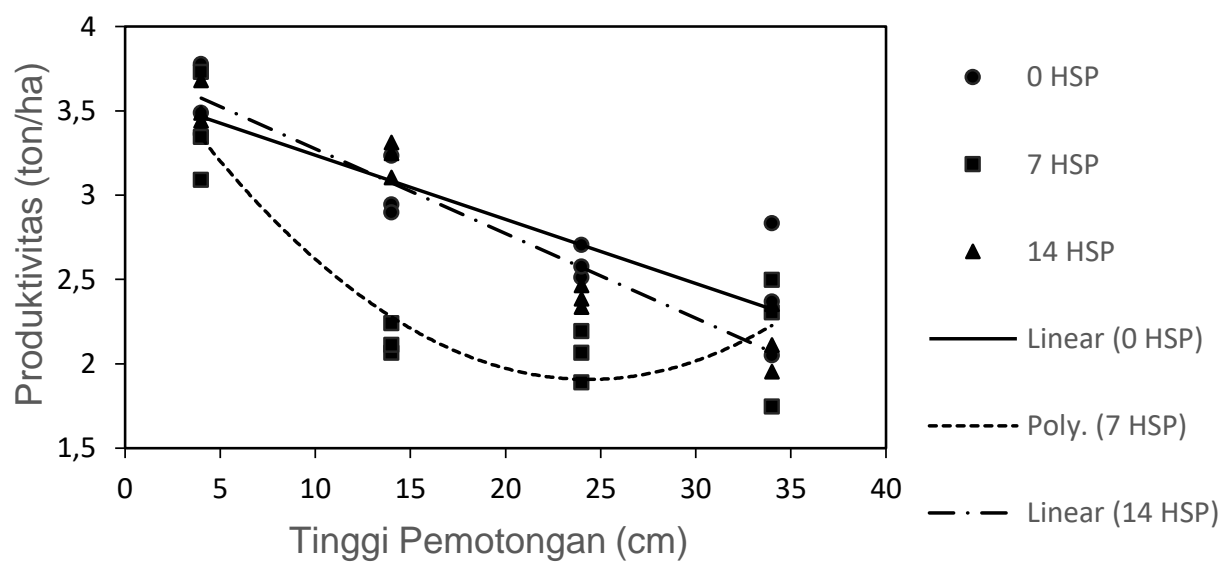

Gambar 10. Hubungan antara tinggi pemotongan tunggul dengan produktivitas padi ratun ketika tunggul dipotong pada $0 \mathrm{HSP}\left(\mathrm{Y}=-0,038 \mathrm{X}+3,6172 ; \mathrm{R}^{2}=0,7905 ; P<0,05\right), 7 \mathrm{HSP}\left(\mathrm{Y}=0,0035 \mathrm{X}^{2}-\right.$ $\left.0,1683 \mathrm{X}+3,9579 ; \mathrm{R}^{2}=0,8317 ; P<0,05\right)$ dan $14 \mathrm{HSP}\left(\mathrm{Y}=-0,0502 \mathrm{X}+3,7762 ; \mathrm{R}^{2}=0,9213\right.$; $P<0,05)$ 

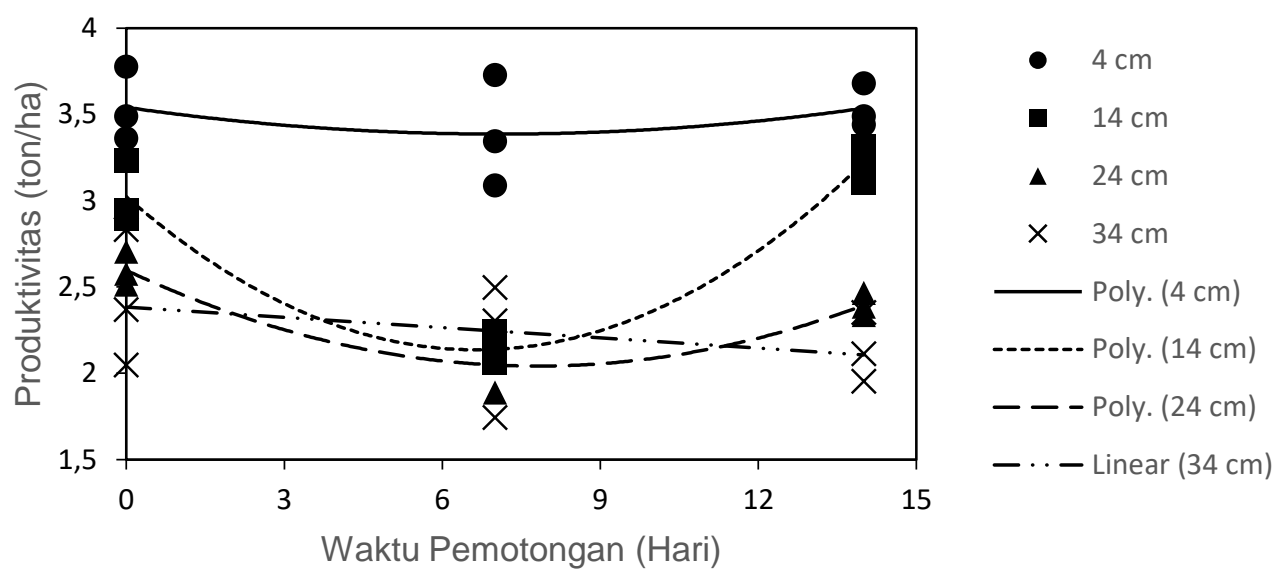

Gambar 11. Hubungan antara waktu pemotongan tunggul dengan produktivitas padi ratun ketika tunggul dipotong setinggi $4 \mathrm{~cm}\left(Y=0,0031 X^{2}-0,0438 X+3,5413 ; R^{2}=0,1227 ;(P=0.4844)\right), 14 \mathrm{~cm}$ $\left(Y=0.0201 X^{2}-0.267 X+3.024 ; R^{2}=0.9499 ; P<0,05\right), 24 c m\left(Y=0.0091 X^{2}-0.1425 X+2.5973 ;\right.$

$\left.R^{2}=0.8621 ; P<0,05\right)$ dan $34 \mathrm{~cm}$ di atas permukaan $\operatorname{tanah}\left(Y=-0,0198 X+2,384 ; R^{2}=0,1388\right.$; $\mathrm{P}=0.4606)$.

Pengaruh perbedaan tinggi pemotongan tunggul berinteraksi dengan waktu pemotongan tunggul. Berdasarkan Gambar 11., waktu pemotongan tunggul tidak berpengaruh nyata terhadap produktivitas padi ratun bila pemotongan tunggul dilakukan setinggi $4 \mathrm{~cm}$ dan $34 \mathrm{~cm}$ di atas permukaan tanah, namun terdapat pengaruh waktu pemotongan pada pemotongan tunggul setinggi $14 \mathrm{~cm}$ dan $24 \mathrm{~cm}$. Pada pemotongan tunggul setinggi $14 \mathrm{~cm}$ di atas permukaan tanah, produktivitas terendah sebesar 2,14 ton/ha diperoleh bila tunggul dipotong pada 6,64 HSP (7 HSP), sedangkan pada pemotongan tunggul setinggi $34 \mathrm{~cm}$ di atas permukaan tanah produktivitas terendah sebesar 2,04 ton/ha diperoleh bila pemotongan tunggul dilakukan pada 7,83 HSP (8 HSP).

\section{KESIMPULAN}

Waktu pemotongan tunggul sisa panen hanya berpengaruh nyata terhadap diameter akar dengan waktu pemotongan terbaik 10 HSP yang menghasilkan diameter terbesar $0,89 \mathrm{~mm}$, ketika dilakukan pemotongan tunggul setinggi $4 \mathrm{~cm}$ di atas permukaan tanah, namun tidak berpengaruh nyata terhadap sifat perakaran lainnya. Fase vegetatif yang paling lama (44 hari) dan produktivitas gabah yang paling tinggi (3,39-3,54 ton/ha) diperoleh bila tunggul dipotong setinggi $4 \mathrm{~cm}$ di atas permukaan tanah, namun perbedaan waktu pemotongan tunggul tidak berpengaruh nyata terhadap kedua variabel tersebut. 


\section{DAFTAR PUSTAKA}

Abdulrachman, S., E. Suhartatik, Erdiman, Susilawati, Z. Zaini, A. Jamil, M. J. Mejaya, P. Sasmita, B. Abdulah, Suwarno, Y. Baliadi, A. Dhalimi, Sujinah, Suharma dan E. S. Ningrum. 2015. Panduan Teknologi Budidaya Padi Salibu. $<$ http://bbpadi.litbang. pertanian.go.id/images/publikasi/ panduanteknis/Salibu.pdf>. Diakses pada 21 Agustus 2016.

Azura, A. E., J. Shamshuddin dan C. I. Fauziah. 2011. Root elongation, root surface area and organic acid by rice seedling under $\mathrm{Al}^{3+}$ and/or $\mathrm{H}^{+}$stress. American Journal of Agricultural and Biological Sciences 6: 324-331.

Bertrand-Morvan, A., J. Boucaud and M. Prud'homme. 1999. Influents of initial levels of carbohydrates, fructans, nitrogen and soluble proteins on regrowth of Lolium perenne L. Cv. Bravo following defoliation. Journal of Experimental Botany 50: 1817-1826.

Blum, A. and J. T. Ritchie. 1984. Effect of soil surface water content on shorgum root distribution in the soil. Field Crops Research 8: 169-176.

Chauhan, J. S., B. S. Vergara and F. S. S. Lopez. 1985. Rice Ratooning. IRRI, Manila.

Chiangmai, P. N. dan P. Yodmingkhwan. 2011. Competition of root and shoot growth between cultivated rice (Oryza sativa L.) and common wild rice (Oryza rufipogon Griff.) grown under different phosphorus levels. Songklanakarin Journal of Science and Technology 33: 685-692.

Corbesier, L., G. Bernier and C. Perlleux. 2002. C:N ratio increases in phloem sap during floral transition of long day plants Sinapis alba and Arabidopsis thaliana. Plant Cell Physiol 43: 684-688.

Dunand, R. and Saichuk, J. 1999. Rice Growth and Development. In: Saichuk, J. (Eds). Lousiana Rice Production Handbook. LSU Ag. Center, Lousiana. p: 34-45.

Gregory, P. J. 2006. Plant Roots: Growth, Activity and Interaction with Soils. Blackwell Publishing, Oxford.

Ichii, M. and N. Ogaya. 1985. Application of ratoon traits obtained by higher cutting for estimation of precentages of ripened grains in rice plants. Japan. J. Breed 35: 311-316.

Ichii, M. 1988. Some Factors Influencing the Growth of Rice Ratoon. In: W. H. Smith, V. Kumble and E. P. Cervantes (Eds). Rice Ratooning. International Rice Research Institute, Manila. p: 41-46.

Kitomi, Y., H. Kitano and Y. Inukai. 2011. Moleculer mechanism of crown root initiation and the different mechanisms between crown root and radicle in rice. Plant Signal Behavior 6:1270-1278.

Makarim, A.K. and E. Suhartatik. 2006. Morfologi dan Fisiologi Tanaman Padi. Balai Besar Penelitian Padi, Subang.

Morita, S. dan J. Abe. 1994. Modelling Root System Morphology in Rice. In: Davis, T. D. dan B. E. Haissig (Eds). Biology of Adventitous Root Formation. Plenum Press, New York. 
Morita, S., dan K. Nemoto. 1995. Morphology and Anatomy of Rice Roots with Special Reference to Coordination in Organo- and Histogenesis. In: Baluska, F., M. Ciamporova, S.A. Gasparikova dan O. Barlow (Eds). Structure and Function or Roots. Kluwer Academic Publisher, Massachusetts.

Nainggolan, K., I. M. Harahap dan Erdiman. 2013. Teknologi Melipatgandakan Produksi Padi Nasional. Grasindo, Jakarta.

Oad, F. C., P. S. Cruz, N. Nemon, N. L. Oad and Z. U. Hassan. 2002. Rice ratoon management. Journal of Applied Sciences 2: 29-35.

Schneider, H. M., J. A. Postma, T. Wojciechowski, C. Kuppe and J. P. Lynch. 2017. Root cortical senescence improves growth under suboptimal availability of $\mathrm{N}, \mathrm{P}$ and $\mathrm{K}$. Plant Physiology 174: 2333-2347.

Schneider, H. M. and J. P. Lynch. 2018. Functional implications of root cortical senescence for soil resource capture. Plant Soil 423: 13-26.

Slaton, N. A., C. A. Beyrouty, W. R. Wells, R. J., Norman and E. E. Gbur. 1990. Root growth and distribution of two short-season rice genotypes. Plant and Soil 121: 269-278.

Vergara, B. S. dan T. T. Chang. 1985. The Flowering Response of the Rice Plant to the Photoperiod. IRRI, Manila 